\title{
Significant Issues of Nuclear Energy Investment Decisions for Energy Importer Countries
}

\author{
Hasan Dinçer (10 ${ }^{1}$ GÜlsüm Sena Uluer (iD ${ }^{2}$
}

Received:19.11.2020; Revised:25.02.2021; Accepted:20.05.2021

\begin{abstract}
Nuclear energy investments are important for the social and economic development of countries. Thanks to these investments, no carbon gas is released into the atmosphere while providing energy. This situation prevents the environmental pollution problem. On the other hand, nuclear energy contributes to countries to obtain uninterrupted electricity. However, the installation of nuclear power plants is now difficult. A serious technological infrastructure is required to build these facilities. This situation is especially important for countries that do not yet have nuclear power plants. Additionally, nuclear energy has a positive contribution to the economic growth. In order to increase the use of nuclear energy in these countries, support from nuclear energy companies is required. However, nuclear energy investors may not want to invest in every country. In this study, the factors that affect the investment decisions of nuclear energy investors are analyzed. In this framework, a detailed literature analysis was performed, and 4 different criteria were determined. An analysis was carried out using the Entropy method to determine the most important factor among these factors. According to the results of the analysis, it is determined that the socio-political factors in the country have the most importance in the decisions of nuclear energy investors. Considering these issues, it is understood that countries should pay attention to public acceptance to attract the attention of nuclear energy investors.
\end{abstract}

JEL codes: O13, P28, P48

Keywords: Nuclear Energy Investment; Public Acceptance; Entropy

\section{Introduction}

Economic growth is increasing with raising international trade volume, capital mobility, consumption, sustainability in re-

1 Prof. in The School of Business, Istanbul Medipol University, İstanbul, Turkey, email: hdincer@medipol.edu.tr

2 Graduate Student in The School of Business, İstanbul Medipol University, İstanbul, Turkey, email: gsuluer@st.medipol.edu.tr sources, technology, labour, political stability, and investments in developing countries. Higher amount liquidation in countries rises their monetary and trade activities. Companies and enterprises are giving importance for investments to developing countries which have elevated growing potential, because developed countries reached to top level of growth rate (Malik et al., 2020). Hence, advanced countries' investors found 
attractive developing economies in order to maximize their profit. So, foreign direct investments (FDI) rates are scaling up for developing countries (Asiedu, 2002). Therefore, FDI support to raise hot money flow, developing industries, technologies, and other business activities for developing countries (Zameer et al., 2020).

FDI provides to decrease or close developing countries' economic deficits by creating and reviving sectors. So, it rises production capacity and export rate in international trade while import is falling. With regard of these, unemployment rates reduce thanks to the developing sectors and this will rise social welfare by increasing income level. Another component is dependency. Advancing industrialization, higher amount production and services will decrease dependency to the sources came from outside and, current deficit will become disappear. For example, energy investments are important for a country which have import huge amount of energy resources from outside. Thus, energy investments will reduce down their import rate with closing deficits.

Energy is source for maintaining life such as heating, lighting, producing, cooling, and other needs (Zhong et al., 2020). Energy need and demand increases with rising population. Hence, having and using strong energy resources countries have opportunity to increase sustainability in economic growth (Yuan et al., 2020). Also, energy investments keep its importance day by day with increasing industrialization and consumption ( $\mathrm{Li}$ et al., 2020). However, energy investments require big amount of money, and their cost and risks are also huge (Qiu et al., 2020). Energy investment companies considers lots of factors in order not to fail (Qiu et al., 2020). Financial instruments should also set up to each factor as estimated and analyzed (Zhou et al., 2020). Energy investment amounts can also differ to the types as renewable energy (RE), non-renewable energy (NRE) and nuclear energy.

$\mathrm{RE}$ and nuclear energy investments im- portance rises with increasing $\mathrm{CO} 2$ emission rate and costs to fix its damages (Mikayilov et al., 2020). Moreover, government and many of international union warn countries to reduce down fossil-based energy resources usages. Additionally, there seemed researches in which $\mathrm{CO} 2$ emission rate decreased, and economic growth increased with raising nuclear energy and RE usage (Yüksel et al., 2020). Therefore, countries are trying to increase RE and nuclear energy supply in production and consumption to catch sustainability targets (Buongiorno et al., 2018). Nuclear energy has low level CO2 emission rate and nuclear power based on electricity generation efficiency is so high with adequate amount of uranium and thorium. When it compared with other resources, nuclear power is more efficient to the other resources. Nuclear energy has role in increasing economic growth. Also, nuclear reactor generated electricity power is low level carbon technology outcome. However, nuclear energy is one of the highest required investment amount energy resources. Therefore, high amount of investment brings high risk and return. Also, investors expect to get quick income in return for investment that made to nuclear project financing. Hence, financial instruments should be ready for the factors which are based on economic, social, political, technological, geographical, and other circumstances. So, nuclear energy investors' decisions in developing countries can be affected by many of factors.

Some factors are considered for nuclear energy investment decisions. Economic stability such as interest rates, inflation rates, exchange rates, price volatility and other components can be main concerns for investors because of they would like to achieve the best return and quick respond to their investment amount. In nuclear energy investments, quick response against to investment amount could be hard, because nuclear power requires huge amount money, and its management is costly with sufficient energy generation (Piłatowska et al., 2020). More- 
over, ecopolitics approaches are thought in order not to expose any negative intervention by that country after investments. For example, foreign investors cannot to fund a project in close economies or were timid while investing in weak regimes governed countries which have inadequate law system (Luqman et al., 2019). Dictatorial and democratic regimes acted different against nuclear power. Some of them used their hegemonistic power to build nuclear energy against to public while some of them was listening public nuclear power opinion. Also, countries limited nuclear energy policies can danger nuclear power project financing and investors could hesitate to fund (Lau et al., 2019). After Fukishima accident, most of country decided to phase out nuclear reactors because they feared nuclear power risks and dangers to health and chose to increase fossil fuel resources and RE. Decommissioning of nuclear reactors can harm to economic growth. However, long lived nuclear reactors cost and damages to environment and health increase risks. Nuclear energy industry shares can decrease and might nuclear power support companies lose stock value after nuclear accidents (Sarkodie \& Adams, 2018). So, nuclear energy investors can withdraw their fund for nuclear power project. Therefore, other resources values can increase, and energy investors could shift. Otherwise, some governments have potential to be persuaded by nuclear energy investors, because they need to decrease dependency, close current deficits and support GDP with increasing production rate and decreasing energy cost. Also, tax and tariffs policies of developing economies are one of the significant considerations for FDI because, companies, countries or others who have fund surplus, do not want to lose money leading by taxes and tariffs (Ozturk, 2017).

On the other hand, social and demographic factors shape investment decision. Labour and managerial skills, education level, age and gender distribution can determine investment scope. For example, high education level countries might not offer cheap labour force. Furthermore, specialization on a work such as automobile sector, textile sector, energy sector or others can be drawback to progress in new sector that is funded. However, nuclear reactor management and process need to well qualified workers to manage nuclear power technology. So, unskilled workers need to train or import skilled worked from other countries. Hence, this will create extra cost for investors (Nazlioglu et al., 2011). Also, public acceptance (PA) influences nuclear reactor projects. If a countries' people do not want to accept nuclear energy, it could be prevented the project and investors plan. After Chernobyl and Fukishima accident, people would not like to nuclear energy usage in their country and nuclear support rate decrease while increasing anti- nuclear activists' rate (Lee \& Chiu, 2011). Therefore, individuals', groups', and organizations' willingness to pay for nuclear energy generated electricity power could reduce and it will adjourn or prevent quick response for return or causes loses. Nuclear energy perceived risk and benefit change to the factors such as government attitude, politicians, polarized media, social media, information transparency, scientific approach, communication channel, economic, social and environmental circumstances, health of people and others.

Another issue is safety of countries, terrorism, and lacking security of borders of economies are risky for FDI returns. Furthermore, any small accident, attacks and insecurity accident in nuclear reactor causes with major disasters for world. So, foreign investors can hesitate dangerous regions in developing countries while funding for nuclear project. Technologic developing potential also give encouragement for foreign investors because technologic capital decreases cost and provide quick response to investment. Nuclear reactors technologies are improving constantly. One of the decommissioning nuclear reactors' reasons is running out nuclear reactors' lifetime. These reactors 
increase accident risk and maintenance and repair works of them rises cost. On the other hand, last technology reactors -Gen IV-also have higher investment amount. Developing artificial intelligence (AI), computational improvements, algorithms, different tests on nuclei or ion and heating temperatures are making for minimizing nuclear accident risk and maximizing profit and proper nuclear waste management with satisfying energy demand and public support (Wolde-Rufael, 2010).

Also, investors care geographic conditions in order to close distribution channels, connect with other suppliers, get the highest efficiency. For example, wind energy investments require correct wind direction locations and close to grids regions. Moreover, nuclear energy investments require close to water and non-fault line regions. So, accurate location choice increases return. Besides, nuclear fuels are mainly uranium and thorium. So, it gives advantage countries who have nuclear fuels in their lands. Hence, nuclear fuels can use in nuclear reactors and export other countries with feasible mining extraction. Therefore, lack of nuclear fuel resources means import cost. With regard of these nuclear fuel cycle technology is also crucial and nuclear reactor technologies are going to be advanced by concerning waste nuclear fuel recycling (Yoo \& Ku, 2009).

On the other hand, countries' need, and demand are attracted attention of investors in order to become first comer gather major amount return by stimulate their economic growth. For instance, energy investment companies can consider funding countries who have dependent foreign energy resources. Nuclear energy demand and consumption rate can change to the other energy resources efficiency and price. If oil, gas, coal, or other alternative energy types' prices reduce down, business, people and government might decrease nuclear energy generation or quit. Therefore, investors could not fund a low demand project financing ( Du et al., 2020).

Thus, there are many of factors and nu- clear investments on energy importer countries to the providing appropriate conditions will acquire benefits for their economies and these factors might influence investors decision making. In this study, it is aimed to evaluate the significant issues that affect the investment decisions of the nuclear energy investors. Within this framework, 4 different factors are defined by conducting a detailed literature review within the scope of the private sector and public sector mixture. In the analysis process, Entropy methodology is taken into consideration to identify the weights of the criteria. Hence, it can be possible to present appropriate strategies for energy importer countries to attract the attention of the nuclear energy investors. In the literature, most of the studies focus on the public acceptance of the nuclear energy and the impact on this energy on the economic development. However, there is a need for a new study that identifies the factors affecting the investment decisions of the companies. Hence, the main contribution of this study is that significant factors are defined to improve nuclear energy investments with an original methodology.

\section{Literature Review}

Nuclear energy has significant role in order to growth economies, develop industries, satisfy needs, demands of energy consumption, and increase economic advantage between countries (Prăvălie \& Bandoc, 2018). Moreover, Sarkodie and Adams (2018) stated that economic growth, political stability, and energy consumption influences environment quality. In addition to that, Kim (2020) denoted that urbanization brings economic growth and rising in greenhouse gas (GHG) rate. Also, said that there is positive relationship between $\mathrm{CO} \sim 2$ emission rate and economic growth. However, nuclear energy and renewable ( $\mathrm{RE}$ ) energy decreases $\mathrm{CO} \sim 2$ emission rate while increasing economic growth rate and breaking economic vulnerability because of fossil fuel-based energy generation which increases $\mathrm{CO} \sim 2$ emission rates 
(Piłatowska et al., 2020; Luqman et al., 2019; Lau et al., 2019; Sarkodie \& Adams, 2018; Ozturk, 2017; Nazlioglu et al., 2011; Lee \& Chiu, 2011; Wolde-Rufael, 2010; Yoo \& Ku, 2009). Also, Alekseev et al. (2020) remarked that coal and gas consumption rate can be reduced down thanks to the nuclear energy generation. So, RE and nuclear energy can mitigate climate change. With regard of these, Dong, Sun, Jiang, and Zeng (2018) specified that China is one of the highest $\mathrm{CO} \sim 2$ rate countries in the world and nuclear energy and RE are promoted to government so they would support with incentives. Besides, Buongiorno et al. (2018) remarked that nuclear energy is low carbon energy to produce electricity. Furthermore, Prăvălie and Bandoc (2018) emphasized that nuclear reactors are beneficial for decarbonization if nuclear waste management can be made properly, because long lived and weak waste management reactors will harm to environment. However, Almutairi, Thoma, and DurandMorat (2018) established two scenarios as business as usual (BAU) and, RE and nuclear energy (RNE) by 2030. In RNE scenario, all countries' GDP rates and employment rates decreased without mitigating climate change except India.

On the other hand, nuclear energy has impact on economic growth and decreasing energy dependency by closing current deficit. As Aydın (2020) explained that Turkish nuclear project in 1970 failed because of financial, administrative, and technical problems. Turkey dealt with Russia and Japan to build nuclear power in order to reduce down gas dependency to Russia. However, trust to government problem, public conflict and environmental concerns problems are still maintaining their existence. Also, Kok and Benli (2017) stated that Turkey import big portion of its energy such as coal and gas from other countries. Hence, it creates a huge current deficit for their economy and nuclear power will decrease the deficit. With regard of these, electricity cost will decrease with dependency. Moreover, Rabinowitz (2016) denoted that Israel failed decades on nuclear power, but they give weight to nuclear energy because of they have limited energy resources. Although Middle East countries have oil resources, they give importance to build nuclear power because of decreasing energy cost, increasing security, international relations' strategy, national security, and civil liberties (Krane et al., 2016). Additionally, Kratochvil and Mišík (2020) studied that Czech Republic and Slovakia attached importance to nuclear energy investments in order not to experience 2009 gas crisis. Moreover, Turkey has thorium reserves, and this nuclear fuel can export (Ağbulut, 2019). All these causes economic growth for countries. Withal, nuclear reactor decommissioning has become a trend in the world after Fukishima nuclear accident. As, Kunsch and Friesewinkel (2014) analysed that nuclear reactor phase-out caused to rise for fossil fuel-based resources, foreign dependency, price volatility, CO 2 emission rate and drawbacks energy security in Belgium. Besides, Italia stopped nuclear power and their economies influenced negatively (Esposto, 2008). Also, Mauger (2018) expressed that nuclear reactor shut down can increase energy generation cost as well in Fessenheim nuclear reactor that phased out so costly because of wrong legislation. Furthermore, Kim and Jeon (2020) found that nuclear energy decommissioning and high nuclear reactor expenditures lead to lose nuclear energy industry value added and it reacts to increase values added of RE industry. Thus, Lopatta and Kaspereit (2014) showed that nuclear energy support companies' share prices reduced down and get negative stock market returns after Fukishima accident. However, RE support companies were not influenced and get abnormal returns.

Nuclear energy is so costly and requires higher amount investments. As, Buongiorno et al. (2018) denoted that decarbonization cost will decrease when nuclear power cost reduced. Moreover, Gupta, Nowlin, Ripberger, Jenkins-Smith, and Silva (2019) remarked 
that nuclear energy supports depends on nuclear reactor accident and also, nuclear power supports will rise if oil, gas, and coal resources become expensive and scarce. Otherwise, Luqman et al. (2019) researched that oil price do not affect nuclear energy consumption but RE consumption is influenced. Also, Ozturk (2017) explained that relationship between oil rent price and GDP per capita is negative in Latin America. Moreover, Lee and Chiu (2011) analyzed that relationship between nuclear energy consumption and oil prices is positive in long term. Furthermore, noted that nuclear energy generation decreased businesses' operation cost by providing energy security and reducing down cost of electricity when compared fossil fuel-based electricity generation cost (dos Santos, Rosa, Arouca, \& Ribeiro, 2013; AlFarra \& Abu-Hijleh, 2012).

So, nuclear energy investments are important for public, countries' economies and businesses. According to International Energy Agency (IEA) and International Atomic Energy Agency (IAEA) report, nuclear energy should be given importance and required high amount investment, so financial constraints are also crucial in solving nuclear power investment problems (Dalton, 2019; Shepherd, 2018; Kratochvil \& Miš́k, 2020). So, Melikoglu (2016) emphasized that Turkey should take precautions to protect economy sustainability, because they spent $90 \%$ of energy investments to nuclear and RE and $10000 \mathrm{~W}$ energy usage estimated by 2023 , but it might be $2400 \mathrm{~W}$. Thus, science communication provides funding, credibility, and publication as (Berdahl, Bourassa, Bell, \& Fried, 2016) stated. As Sainati, Locatelli, and Smith (2019) stated that completion risk, prescriptive regulatory oversight and limited nuclear power liability are problems for nuclear reactor project financing. Besides, Saidi and Mbarek (2016) remarked that existence causality between labour rate, capital, and $\mathrm{CO} 2$ rate. Withal, Apergis and Payne analysed that labour force, real gross fixed capital and GDP have positive relationship with nuclear consumption in long term. Otherwise, Kim (2020) stated that FDI and economic growth increases GHG rates while manufacturing industry share, RE and nuclear energy were reducing down GHG rates. Also, Jensen-Eriksen (2020) remarked that businesses offered fifth reactors project proposal as green energy resources after Finland government rejected. With regard of these, Siqueira et al. (2019) studied that time and management of construction, reactor technology, energy policies, public opinion, life cycle and cost management are main consideration in order to achieve nuclear power projects, provide electricity generation security and get quick response return. Also, Gozgor and Demir said that nuclear power returns were not given quick response. Heffron (2013) added that construction management is also important as economical aspects. Moreover, Zawalińska, Kinnunen, Gradziuk, and Celińska-Janowicz (2020) said that location choice in order to get the highest efficiency is important for nuclear reactor construction and other energy resources projects which requires high amount investments. Also, Gagarinskiy (2018) remarked that nuclear reactor size is significant in order to easy access, training and experiments as small nuclear reactors and Russian nuclear energy ships were appropriate for Arctic. In addition to that, small reactors would be more suitable as investment amount for Africa economies and their developing, because they have limited capital and electricity deficit Kessides (2014). Nuclear energy technology export has also contributed economic growth in Russia and negative nuclear energy in Korea image change after exporting nuclear technology to UAE (Aalto, Nyyssönen, Kojo, \& Pal, 2017; Roh \& Kim, 2017).

However, nuclear reactor cost change to the system technology development. With advancing technology, nuclear reactors have become fast and more sufficient while meeting energy demand of population and industry. As, Gao, Nam, Jang, and Ko (2019) stated that Gen IV technology nuclear reac- 
tors are cost-effective reactors which provides nuclear fuel cycle and uranium utilization. Bedenko, Ghal-Eh, Lutsik, and Shamanin (2019) tested that Gen IV technology reactors are economical with thorium-plutonium nuclear fuel cycle and computational developments will solve nuclear power engineering. Also, Belokrylov, Bol'shukhin, Komissarov, Petrunin, and Poverennov (2020) denoted that computational system will provide fast business process and outcome from nuclear reactor. In addition to that, Poinssot, Bourg, and Boullis (2016) added as nuclear fuel cycle has a role for decreasing GHG emission rate and rising economic sustainability. According to the Gralla et al. (2016) stated that nuclear waste management, risk and social aspects were mentioned lower than economy, governments, and environment for nuclear energy sustainability discussion.

Huhtala and Remes (2017) said that nuclear power support rate will fall down when perceived risk rate on people rises that lead to nuclear reactor accidents. Therefore, nuclear energy return could be in danger because of social cost. Hence, Geng, Liu, Zhou, and Yang (2018) studied that nuclear energy development depends on public opinion with government and risk management should made properly for environment. With regard of these, perceived risk and benefits were shaped by $\mathrm{CO} \sim 2$ emission rate and trust of information. Therefore, nuclear willingness to pay changes to energy resources types (Vainio et al., 2017). For example, Murakami, Ida, Tanaka, and Friedman (2015) determined that consumers' willingness to pay for nuclear energy and RE generated electricity in USA and Japan. USA consumers are more willing than Japanese. Additionally, wiliness to pay RE generated electricity rate is more than nuclear powerbased electricity. Also, Jun, Kim, Jeong, and Chang (2010) stated that nuclear energy technology and social perception have impact on willingness to pay for electricity energy. Although strong opposers of nuclear energy in UK, they are willing to pay for nuclear power with developing R\&D studies (Contu \& Mourato, 2020).

\section{Analysis Results}

In the study, the most important issues to attract the attention of nuclear energy investors are analyzed. In this framework, first of all, the factors affecting the investment decisions of these investors were determined. Details of these criteria are given in Table 1.

Table 1: The List of the Criteria

\begin{tabular}{lc}
\hline Factors & $\begin{array}{c}\text { Supported } \\
\text { Literature }\end{array}$ \\
\hline $\begin{array}{l}\text { Socio-Political } \\
\text { Conditions (C1) }\end{array}$ & (Piłatowska et al., \\
\hline Demographic & (Sarkodie and \\
Factors (C2) & Adams, 2018) \\
\hline Geopolitical & (Lee and Chiu, \\
Issues (C3) & 2011) \\
\hline Macroeconomic & (Lau et al., 2019) \\
Stability (C4) & \\
\hline
\end{tabular}

Table 1 states that there are mainly 4 different factors that have an impact on the decisions of the nuclear energy investors. Within this context, socio-political issues are also important in investment decisions of nuclear energy investors. In this context, it increases the anxiety of nuclear energy investors when public acceptance cannot be achieved. Additionally, the demographic factors of the countries are also taken into consideration. For instance, when there is high population in the country, the demand for the electricity increases. This situation has a positive impact on the decisions of these investors. Furthermore, geopolitical factors in the country also play an important role in this process. In this framework, nuclear energy investors do not prefer countries with fault lines. the macroeconomic factors affect this decision. In other words, nuclear energy investors prefer to make investment in the countries which have high economic growth 
and low unemployment problem. In addition, 3 different experts evaluate these criteria by considering 5 different scales. These people are the academicians of nuclear energy investment. They have at least 20-year experience regarding this issue so that it is thought that these people have sufficient knowledge to evaluate the criteria. The opinions of all experts have the same influence on the findings. In most of the MCDM methods, the opinions of 3 or 4 experts are taken into consideration (J. Liu et al., 2021; Y. Liu et al., 2021; Zhao et al., 2021; Yang et al., 2021). Hence, it is obvious that selecting 3 different experts is quite optimal in this regard. The details of the evaluations are given on Table 2 .

Table 2: Experts' Evaluations

\begin{tabular}{ccccc}
\hline Criteria & C1 & C2 & C3 & C4 \\
\hline Evaluation of & Expert $\mathbf{1}$ & & \\
C1 & 0 & 2 & 2 & 1 \\
C2 & 1 & 0 & 2 & 1 \\
C3 & 2 & 2 & 0 & 1 \\
C4 & 5 & 5 & 5 & 0 \\
Evaluation of & Expert 2 & & \\
C1 & 0 & 2 & 2 & 2 \\
C2 & 2 & 0 & 1 & 1 \\
C3 & 2 & 3 & 0 & 2 \\
C4 & 5 & 4 & 5 & 0 \\
Evaluation of Expert 3 & & \\
C1 & 0 & 2 & 3 & 3 \\
C2 & 1 & 0 & 3 & 2 \\
C3 & 4 & 2 & 0 & 1 \\
C4 & 5 & 5 & 4 & 0 \\
\hline \multicolumn{7}{r}{}
\end{tabular}

Furthermore, in the analysis process, Entropy methodology is considered. Within this framework, firstly, pairwise comparison matrix is generated by considering the average values of expert evaluations. This matrix is demonstrated in Table 3.

Moreover, the normalized matrix is constructed by dividing each value to the sum of the columns. This matrix is indicated on
Table 3: Pairwise Comparison Matrix

\begin{tabular}{ccccc}
\hline Criteria & C1 & C2 & C3 & C4 \\
\hline C1 & 0.00 & 2.00 & 2.33 & 2.00 \\
C2 & 1.33 & 0.00 & 2.00 & 1.33 \\
C3 & 2.67 & 2.33 & 0.00 & 1.33 \\
C4 & 5.00 & 4.67 & 4.67 & 0.00 \\
\hline
\end{tabular}

Table 4.

Table 4: Normalized Matrix

\begin{tabular}{ccccc}
\hline Criteria & C1 & C2 & C3 & C4 \\
\hline C1 & 0.00 & 0.22 & 0.26 & 0.43 \\
C2 & 0.15 & 0.00 & 0.22 & 0.29 \\
C3 & 0.30 & 0.26 & 0.00 & 0.29 \\
C4 & 0.56 & 0.52 & 0.52 & 0.00 \\
\hline
\end{tabular}

In the next stage, the weights of the criteria are calculated. The analysis results are shown in Table 5.

Table 5 shows that socio-political conditions play the most significant role for the decision of the nuclear energy investors. In addition, demographic factors and geopolitical issues are other important factors for this situation. On the other side, macroeconomic stability is the least important issue in this respect.

Table 5: The List of the Criteria

\begin{tabular}{lc}
\hline Factors & Weights \\
\hline $\begin{array}{l}\text { Socio-Political } \\
\text { Conditions (C1) }\end{array}$ & 0.2863 \\
\hline $\begin{array}{l}\text { Demographic Factors } \\
(\mathrm{C} 2)\end{array}$ & 0.2485 \\
\hline $\begin{array}{l}\text { Geopolitical Issues } \\
(\mathrm{C} 3)\end{array}$ & 0.2485 \\
\hline $\begin{array}{l}\text { Macroeconomic } \\
\text { Stability (C4) }\end{array}$ & 0.2167 \\
\hline
\end{tabular}




\section{Discussion and Conclusion}

Countries apply different policies to ensure their energy supply security. The main purpose in this process is for countries to produce their own energy. This situation positively affects the current account balance of the countries. In addition, the energy to be produced must be uninterrupted. Otherwise, efficiency in energy use will decrease. In addition to the mentioned issues, carbon gas should not be released into the atmosphere during the energy production process. In this way, the environmental pollution problem will be prevented. This situation will contribute to both the social and economic development of the country. Nuclear energy is a type of energy that contributes to the achievement of these goals. Thanks to the use of nuclear energy, it is possible to increase the energy supply security of countries.

The most important disadvantage in the nuclear energy process is that these power plants are very difficult to establish. There is a need for very serious technical equipment in nuclear power plants. Therefore, countries that do not have nuclear power plants should get support from companies that are experts in this field. On the other hand, nuclear energy investors do not want to invest in every country. In this study, it is aimed to determine the most important factors that attract the attention of nuclear energy investors. In this context, 4 different factors that are effective in this issue have been determined. Taking the Entropy method into consideration, the importance weights of these factors have been calculated. It is concluded that sociopolitical conditions play the most significant role for the decision of the nuclear energy investors. Moreover, demographic factors and geopolitical issues are other important factors for this situation. On the other side, macroeconomic stability is the least important issue in this respect.

Considering these issues, it is understood that countries should pay attention to public acceptance in order to attract the attention of nuclear energy investors. There may be a negative opinion of the public towards the use of nuclear energy in a country. This situation is one of the factors that make nuclear energy investors nervous. Therefore, investors prefer to have no social backlash in the countries they plan to invest in. In this context, countries should take certain measures to improve public acceptance in a positive way. For this purpose, the positive effects of the use of nuclear energy on the economy and the environment are clearly communicated to the public. Moreover, nuclear energy is so significant that public and private sectors' cooperation is essential in order to improve these investments. In the future studies, new evaluations can be conducted regarding the analysis of the factors that reduce the costs of the nuclear energy investments.

\section{References}

Aalto, P., Nyyssönen, H., Kojo, M., \& Pal, P. (2017). Russian nuclear energy diplomacy in finland and hungary. Eurasian Geography and Economics, 58(4), 386-417.

Ağbulut, Ü. (2019). Turkey's electricity generation problem and nuclear energy policy. Energy Sources, Part A: Recovery, Utilization, and Environmental Effects, 41(18), 2281-2298.

Alekseev, P., Blandinskii, V. Y., Balanin, A., Grol', A., Nevinitsa, V., Teplov, P., ... others (2020). Efficiency assessment of nuclear energy development scenarios for russia using multi-criteria analysis. Atomic Energy, 128, 1-4.

AlFarra, H. J., \& Abu-Hijleh, B. (2012). The potential role of nuclear energy in mitigating $\mathrm{co} 2$ emissions in the united arab emirates. Energy Policy, 42, 272-285.

Almutairi, K., Thoma, G., \& Durand-Morat, A. (2018). Ex-ante analysis of economic, social and environmental impacts of large-scale renewable and nuclear energy targets for global electricity generation by 2030. Sustainability, 10(8), 2884.

Asiedu, E. (2002). On the determinants of foreign direct investment to developing countries: is africa different? World development, 30(1), 107-119.

Aydın, C. İ. (2020). Nuclear energy debate in turkey: Stakeholders, policy alternatives, and governance issues. Energy Policy, 136, 111041.

Bedenko, S., Ghal-Eh, N., Lutsik, I., \& Shamanin, I. (2019). A fuel for generation iv nuclear energy system: Isotopic composition and radiation characteristics. Applied Radiation and Isotopes, 147, 189-196. 
Belokrylov, P. Y., Bol'shukhin, M., Komissarov, K., Petrunin, V., \& Poverennov, E. Y. (2020). Integration of the computational validation process for reactor equipment into a single information space to create digital doppelgangers of nuclear energy facilities. Atomic Energy, 127(6), 339345.

Berdahl, L., Bourassa, M., Bell, S., \& Fried, J. (2016). Exploring perceptions of credible science among policy stakeholder groups: Results of focus group discussions about nuclear energy. Science Communication, 38(3), 382-406.

Buongiorno, J., Parsons, J. E., \& Petti, D. A. (2018). Should nuclear energy play a role in a carbonconstrained world?

Contu, D., \& Mourato, S. (2020). Complementing choice experiment with contingent valuation data: Individual preferences and views towards iv generation nuclear energy in the uk. Energy Policy, 136, 111032

Dalton, D. (2019). How governments can remove barriers to investment in nuclear energy. Atw. In ternationale Zeitschrift fuer Kernenergie, 64(10), 452-453.

Dong, K., Sun, R., Jiang, H., \& Zeng, X. (2018). Co2 emissions, economic growth, and the environmental kuznets curve in china: what roles can nuclear energy and renewable energy play? Journal of cleaner production, 196, 51-63.

dos Santos, R. L. P., Rosa, L. P., Arouca, M. C., \& Ribeiro, A. E. D. (2013). The importance of nuclear energy for the expansion of brazil's electricity grid. Energy Policy, 60, 284-289.

Du, L., Dinçer, H., Ersin, İ., \& Yüksel, S. (2020). It2 fuzzy-based multidimensional evaluation of coal energy for sustainable economic development. Energies, 13(10), 2453.

Esposto, S. (2008). The possible role of nuclear energy in italy. Energy policy, 36(5), 1584-1588.

Gagarinskiy, A. Y. (2018). Russian nuclear energy technologies for the development of the arctic. Atw. Internationale Zeitschrift fuer Kernenergie, 63(3), 149-152.

Gao, R., Nam, H. O., Jang, H., \& Ko, W. I. (2019). The economic competitiveness of promising nuclear energy system: A closer look at the input uncertainties in lcoe analysis. International Journal of Energy Research, 43(9), 3928-3958.

Geng, L., Liu, T., Zhou, K., \& Yang, G. (2018). Can power affect environmental risk attitude toward nuclear energy? Energy Policy, 113, 87-93.

Gralla, F., John, B., Abson, D. J., Møller, A. P. Bickel, M., Lang, D. J., \& von Wehrden, H. (2016). The role of sustainability in nuclear energy plans - what do national energy strategies tell us? Energy research $\mathcal{G}$ social science, 22, 94-106.

Gupta, K., Nowlin, M. C., Ripberger, J. T., JenkinsSmith, H. C., \& Silva, C. L. (2019). Tracking the nuclear 'mood'in the united states: Introducing a long term measure of public opinion about nuclear energy using aggregate survey data. Energy Policy, 133, 110888
Heffron, R. J. (2013). Nuclear energy policy in the united states 1990-2010: A federal or state responsibility? Energy policy, 62, 254-266.

Huhtala, A., \& Remes, P. (2017). Quantifying the social costs of nuclear energy: Perceived risk of accident at nuclear power plants. Energy Policy, 105, 320-331.

Jensen-Eriksen, N. (2020). Looking for cheap and abundant power: Business, government and nuclear energy in finland. Business History, 1-22.

Jun, E., Kim, W. J., Jeong, Y. H., \& Chang, S. H. (2010). Measuring the social value of nuclear energy using contingent valuation methodology. Energy Policy, 38(3), 1470-1476.

Kessides, I. N. (2014). Powering africa s sustainable development: The potential role of nuclear energy. Energy Policy, 74, S57-S70.

Kim, S. (2020). The effects of foreign direct investment, economic growth, industrial structure, renewable and nuclear energy, and urbanization on korean greenhouse gas emissions. Sustainability, 12(4), 1625.

Kok, B., \& Benli, H. (2017). Energy diversity and nuclear energy for sustainable development in turkey. Renewable energy, 111, 870-877.

Krane, J., Jaffe, A. M., \& Elass, J. (2016). Nuclear energy in the middle east: Chimera or solution? Bulletin of the Atomic Scientists, 72(1), 44-51.

Kratochvil, P., \& Mišík, M. (2020). Bad external actors and good nuclear energy: Media discourse on energy supplies in the czech republic and slovakia. Energy Policy, 136, 111058.

Kunsch, P. L., \& Friesewinkel, J. (2014). Nuclear energy policy in belgium after fukushima. Energy policy, 66, 462-474.

Lau, L.-S., Choong, C.-K., Ng, C.-F., Liew, F.-M., \& Ching, S.-L. (2019). Is nuclear energy clean? revisit of environmental kuznets curve hypothesis in oecd countries. Economic Modelling, 77, 1220

Lee, C.-C., \& Chiu, Y.-B. (2011). Oil prices, nuclear energy consumption, and economic growth: New evidence using a heterogeneous panel analysis. Energy Policy, 39(4), 2111-2120.

Li, X., Zhu, S., Yüksel, S., Dinçer, H., \& Ubay, G. G. (2020). Kano-based mapping of innovation strategies for renewable energy alternatives using hybrid interval type-2 fuzzy decision-making approach. Energy, 211, 118679.

Liu, J., Lv, J., Dinçer, H., Yüksel, S., \& Karakuş, H. (2021). Selection of renewable energy alternatives for green blockchain investments: A hybrid it2-based fuzzy modelling. Archives of Computational Methods in Engineering, 1-15.

Liu, Y., Gong, X., Yüksel, S., Dinçer, H., \& Aydın, R. (2021). A multidimensional outlook to energy investments for the countries with continental shelf in east mediterranean region with hybrid decision making model based on ivif logic. Energy Reports, 7, 158-173.

Lopatta, K., \& Kaspereit, T. (2014). The crosssection of returns, benchmark model parameters, and idiosyncratic volatility of nuclear energy 
firms after fukushima daiichi. Energy Economics, 41, 125-136.

Luqman, M., Ahmad, N., \& Bakhsh, K. (2019). Nuclear energy, renewable energy and economic growth in pakistan: Evidence from non-linear autoregressive distributed lag model. Renewable Energy, 139, 1299-1309.

Malik, M. Y., Latif, K., Khan, Z., Butt, H. D., Hussain, M., \& Nadeem, M. A. (2020). Symmetric and asymmetric impact of oil price, fdi and economic growth on carbon emission in pakistan: Evidence from ardl and non-linear ardl approach. Science of the Total Environment, 726, 138421.

Mauger, R. (2018). Forced nuclear energy reactors shutdown in france: the energy transition act's mechanisms. The Journal of World Energy Law G Business, 11(3), 270-281.

Melikoglu, M. (2016). The role of renewables and nuclear energy in turkey s vision 2023 energy targets: Economic and technical scrutiny. Renewable and sustainable energy reviews, 62, 1-12.

Mikayilov, J. I., Mukhtarov, S., Dinçer, H., Yüksel, S., \& Aydın, R. (2020). Elasticity analysis of fossil energy sources for sustainable economies: A case of gasoline consumption in turkey. Energies, 13(3), 731.

Murakami, K., Ida, T., Tanaka, M., \& Friedman, L. (2015). Consumers' willingness to pay for renewable and nuclear energy: A comparative analysis between the us and japan. Energy Economics, 50, 178-189.

Nazlioglu, S., Lebe, F., \& Kayhan, S. (2011). Nuclear energy consumption and economic growth in oecd countries: Cross-sectionally dependent heterogeneous panel causality analysis. Energy Policy, 39(10), 6615-6621.

Ozturk, I. (2017). Measuring the impact of alternative and nuclear energy consumption, carbon dioxide emissions and oil rents on specific growth factors in the panel of latin american countries. Progress in Nuclear Energy, 100, 71-81.

Piłatowska, M., Geise, A., \& Włodarczyk, A. (2020). The effect of renewable and nuclear energy consumption on decoupling economic growth from co2 emissions in spain. Energies, 13(9), 2124.

Poinssot, C., Bourg, S., \& Boullis, B. (2016). Improving the nuclear energy sustainability by decreasing its environmental footprint. guidelines from life cycle assessment simulations. Progress in $\mathrm{Nu}$ clear Energy, 92, 234-241.

Prăvălie, R., \& Bandoc, G. (2018). Nuclear energy: between global electricity demand, worldwide decarbonisation imperativeness, and planetary environmental implications. Journal of environmental management, 209, 81-92.

Qiu, D., Dinçer, H., Yüksel, S., \& Ubay, G. G. (2020). Multi-faceted analysis of systematic risk-based wind energy investment decisions in e7 economies using modified hybrid modeling with it2 fuzzy sets. Energies, 13(6), 1423.

Rabinowitz, O. (2016). Nuclear energy and desalination in israel. Bulletin of the Atomic Scientists, 72(1), 32-38.
Roh, S., \& Kim, D. (2017). Effect of fukushima accident on public acceptance of nuclear energy (fukushima accident and nuclear public acceptance). Energy Sources, Part B: Economics, Planning, and Policy, 12(6), 565-569.

Saidi, K., \& Mbarek, M. B. (2016). Nuclear energy, renewable energy, co2 emissions, and economic growth for nine developed countries: Evidence from panel granger causality tests. Progress in Nuclear Energy, 88, 364-374.

Sainati, T., Locatelli, G., \& Smith, N. (2019). Project financing in nuclear new build, why not? the legal and regulatory barriers. Energy policy, 129, 111119.

Sarkodie, S. A., \& Adams, S. (2018). Renewable energy, nuclear energy, and environmental pollution: accounting for political institutional quality in south africa. Science of the total environment, 643, 1590-1601.

Shepherd, J. (2018). Our planet will be the loser if we allow nuclear energy to ebb away. Atw. Internationale Zeitschrift fuer Kernenergie, 63(10), 558.

Siqueira, D. S., de Almeida Meystre, J., Hilário, M. Q., Rocha, D. H. D., Menon, G. J., \& da Silva, R. J. (2019). Current perspectives on nuclear energy as a global climate change mitigation option. Mitigation and Adaptation Strategies for Global Change, 24(5), 749-777.

Vainio, A., Paloniemi, R., \& Varho, V. (2017). Weighing the risks of nuclear energy and climate change: trust in different information sources, perceived risks, and willingness to pay for alternatives to nuclear power. Risk analysis, 37(3), $557-569$.

Wolde-Rufael, Y. (2010). Bounds test approach to cointegration and causality between nuclear energy consumption and economic growth in india. Energy Policy, 38(1), 52-58.

Yang, F., Kalkavan, H., Dinçer, H., Yüksel, S., \& Eti, S. (2021). Gaussian-based soft computing approach to alternative banking system for sustainable financial sector. Complexity, 2021.

Yoo, S.-H., \& Ku, S.-J. (2009). Causal relationship between nuclear energy consumption and economic growth: a multi-country analysis. Energy policy, 37(5), 1905-1913.

Yuan, J., Zhang, Z. M., Yüksel, S., \& Dinçer, H. (2020). Evaluating recognitive balanced scorecard-based quality improvement strategies of energy investments with the integrated hesitant 2-tuple interval-valued pythagorean fuzzy decision-making approach to qfd. IEEE Access, 8, 171112-171128.

Yüksel, S., Dinçer, H., \& Uluer, G. S. (2020). The role of technological development on renewable energy usage: An econometric analysis for g7 countries. In Handbook of research on sustainable supply chain management for the global economy (pp. 136-153). IGI Global.

Zameer, H., Yasmeen, H., Zafar, M. W., Waheed, A., \& Sinha, A. (2020). Analyzing the association between innovation, economic growth, and 
environment: divulging the importance of fdi and trade openness in india. Environmental Science and Pollution Research, 27, 29539-29553.

Zawalińska, K., Kinnunen, J., Gradziuk, P., \& Celińska-Janowicz, D. (2020). To whom should we grant a power plant? economic effects of investment in nuclear energy in poland. Energies, 13(11), 2687.

Zhao, Y., Xu, Y., Yüksel, S., Dinçer, H., \& Ubay, G. G. (2021). Hybrid it2 fuzzy modelling with alpha cuts for hydrogen energy investments. International Journal of Hydrogen Energy, 46(13), 8835-8851.

Zhong, J., Hu, X., Yüksel, S., Dinçer, H., \& Ubay, G. G. (2020). Analyzing the investments strategies for renewable energies based on multi-criteria decision model. IEEE Access, 8, 118818-118840.

Zhou, P., Zhou, P., Yüksel, S., Dinçer, H., \& Uluer, G. S. (2020). Balanced scorecard-based evaluation of sustainable energy investment projects with it2 fuzzy hybrid decision making approach. Energies, 13(1), 82. 